\title{
Effects of Web-Based Learning and F2F Learning on Teachers Achievement in Teacher Training Program in Indonesia
}

\author{
https://doi.org/10.3991/ijet.v14i21.10736 \\ Wuryaningsih $\left.{ }^{(}\right)$, Dewi H. Susilastuti, Muhadjir Darwin \\ Universitas Gadjah Mada, Yogyakarta, Indonesia \\ wuryaningsih@mail.ugm.ac.id \\ Adi Cilik Pierewan \\ Universitas Negeri Yogyakarta, Yogyakarta, Indonesia
}

\begin{abstract}
Promoting the reform of teacher professional development (TPD) in the digital era using web-based learning (online and blended learning) appears to be a great innovation in improving teachers skills using technology through computers and Internet networks. Some research revealed that online learning on TPD influences on improving teacher performance; however, the effect had no better results compared to traditional learning. Hence, this study evaluating the policy by examining the effects of web-based learning model, i.e., online and blended learning, and face to face approach on the scores achieved in teacher training. The study adopted the quasi-experimental design with pre-post non-equivalent group design of the intact teacher training program. The participants were 427,189 teachers covering all school levels in Indonesia. Findings suggest that the web-based learning model is more effective in teacher achievement than the $22 \mathrm{f}$, while the female tends to be better than male. Hence, digital constraint is not an obstacle for the teacher in the webbased model. Interestingly, blended learning that emerged as a new trend in elearning proved to be quite promising. These findings provide considerations for the development of a policy for an appropriate TPD model for teachers at different levels.
\end{abstract}

Keywords - Web-based learning, teacher training, online learning, e-learning, Teacher Professional Development (TPD), innovative TPD

\section{Introduction}

ICT integration for teacher professional development (TPD) moves education into the digital age and prepares teachers with the needed skills for the 21st century [1]. Traditional models are deemed no longer suitable for contemporary learning [2] and web 2.0 technologies learning [3] using computers connected to the Internet has become popular [4]. 
Online learning provides opportunities for the goal, structure, and new role that support the change of expertise required in century 21 [1]. Moreover, the use of web 2.0 technologies to overcome obstacles that lesson isolated through features networked [5], so that provides easy learning through the application [6].

Based on those advances for the learning model in the 21st century, the main effect of online learning should be shown by the effectiveness of TPD on teacher performance better than the traditional way. However, the readiness factors of the teacher in the use of applications become an obstacle that may affect teacher performance in TPD [7]. The previous study showed that student learning outcomes on the online [8] and blended [9] classes were better than face-to-face, while the effect on teachers was not known [8].

Some of the comparative studies of online versus face to face learning in the TPD revealed that there were no significant differences [10][11] when also had no negative results in both models [12].

However, another study revealed that the online TPD was not that effective because the teacher was not able to reflect the experience through features available in digital applications, while the digital skill constrained as the primary focus [13]. Indeed, the attitude of teachers towards the use of technology-based learning in the teaching process has the most significant impact on their intention to embrace the model of digital learning, followed similarly by perceived ease of use [14]

In Indonesia, the internet used in teaching and for learning purposes is still low unless it increased rapidly. For instance, at the beginning of the century, internet penetration was less than $1 \%$ but it then to $39 \%$ by the end of 2014 , covering 83.6 million people. However, A commitment was made in 2012 to use technology-based learning when the government of Indonesia agreed along with UNESCO's Declaration on the adoption of the Open Educational Resources (OER) in Paris [15].

Furthermore, the Indonesian government established a new policy of TPD using Web 2.0 technology in teacher training to provide online and blended learning (webbased learning) in 2016, and these became an innovative TPD model in Indonesia. However, the previous study of implementing technology innovation in Indonesia assumed that many projects developed into unsuccessful [16]

Therefore this paper aims to evaluate the Indonesian government's policy of intervening the use of technology in teacher training and examining whether webbased learning influences the teacher's score and whether gender influences teacher achievement.

Previous studies that compared online versus traditional learning in higher education institutions were widely practiced [17] through diverse scopes and methods. However, such research on TPD remains rare in almost all countries was also restricted [18]. Moreover, existing studies is a lack of large-scale data for use as practical information and in decision making [19]. This research represents a nationwide scale study using a large sample of 427,189 teachers from all levelschildren's kindergarten, primary school, secondary school, high school, and vocational school - from 34 provinces throughout the country. 


\section{$2 \quad$ Literature Review}

\subsection{Teacher professional development (TPD) and teacher performance}

In-service training is one of professional teacher development (TPD) that is systematically conducted to promote their work [20] in improving their ability as a teacher to become professional [21]. Although TPD has no direct impact on students, the effect can be seen in an improvement in teacher knowledge that contributes to enhancing student learning [22][23][24][25]

As seen in the study by [26] on reviewing the quality of TPD, the definition of TPD effectiveness can be very diverse and varied. However, while teachers enhance their abilities such as knowledge, skills, performance, influence in classroom teaching and improve student achievement, the TPD is effective.

Borko [24] maps research within the TPD in three phases related to the elements of the TPD system consisting of TPD Program, Teacher, Facilitator, and Context, as shown in Figure 2.1. First, studies that focus on a PD program, where the researcher studies the TPD program and the relationship to the teacher as a learner regardless of the facilitator and context. Second, researchers studied a TPD program with more than one facilitator with different places and explored the relationship between facilitators, TPD programs, and teachers as learners. Third, research that focuses on the comparison of TPD programs that occur in many places. The researcher studies the relationship between the four elements in the system.

Desimone [27] also provides a different framework with Borko [24] for TPD evaluation, as presented in Figure 1. which has also been reviewed by [28]. The result concluded that: 1) the core features of TPD were about content-focused, active learning, coherence, duration, and collective participation; 2) how TPD affected teacher knowledge and practice in classrooms and student learning; 3) contextual factors such as the characteristics of students, teachers and schools would affect the effectiveness of the TPD.

Based on Borko [24] framework, this study compares the different models in the TPD program and looks at the relationship with the teacher as a learner to examine the effect of differences in treatment in the TPD program to the scores obtained by the teacher at the end of the program. The score reflects the teacher's knowledge gained in training. Furthermore, based on Desimone (2009), the study evaluates how TPD influences teacher pedagogical and professional knowledge at the end of the training. Furthermore, contextual factors, teacher characteristics such as school level and gender as a confounding variable influenced the effect of the TPD model.

\section{$2.2 \quad$ TPD traditional}

TPD is identical to teacher training (in-service teacher) with allocation funds are quite large every year, but the results are ineffective because the teacher is passive and lacks the opportunity to collaborate and does not support teacher teaching practices [29], where participants in a passive position [30] with one-way communication 
[31]. Training usually takes a long time, while at the end of the activity, the knowledge is lost [32]. However, face-to-face TPD has the advantage of interaction in interpersonal communication where facial expressions and gestures enrich communication and obtain direct responses, and participants are in activities to completion.

\subsection{TPD Model in the Digital Age (Web-based model: the online and the blended learning )}

The web-based model was the generation presented in the digital era [33]. The online learning initiative was an asynchronous activity that developed from the tradition of distance education [34] and provided opportunities for interactive learning [35].

Online learning, e-learning, or web-based learning is a term used interchangeably in several studies [36]. In the digital era, TPD developed in pedagogical practice into innovation from the traditional model to online learning using a computer connected to the internet, where ICT as a tool for pedagogical change [37][38]. [39] described it as the use of web-based technology that allowed information to be available without any distance and time constraints.

Blended learning subsequently emerged as a new trend [40] that combined online and face-to-face learning in meeting sessions [41] providing a combined instructional approach to teachers more broadly [42]. Blended learning also provides access to practical communities and opportunities [43] for teachers with tight schedules at school [42] as well as online learning. Furthermore, teachers still have the opportunity to apply teaching techniques in classroom practice [42][44]. Hence, blended learning reduce the limitations while taking advantage of the two previous modes [45] and affect TPD positively [46]. However, while the experience in the class was absent, blended was no better than the others [47]. Moreover, innovative TPD in the form of online and blended was critical for TPD skills needed by teachers in the digital era [19].

There is the newest generation called a mobile model [33], where learning with devices that are smarter, lighter, and sophisticated so that they can be carried anywhere including mobile phones and other portable ICT equipment. However, this is not relevant enough to this study.

\subsection{Web-based learning and teacher performance}

ICT integration in education in the 21st century has brought positive changes to the teaching process [48] through the application of learning [49]. Online TPD is an innovation [50] in improving the digital skills of teachers in using computers connected to the internet for their professional interests [51] which increase the scores, skills [52] also knowledge and behavior in using technology [51].

Learning through the application produce ease of learning [6] also knowledge, skills, and integration for teachers with unlimited access and are directly connected to learning resources [53] without any time and space constraints [54]. Hence, it can 
serve the teacher with a tight schedule [55]. However, teacher readiness in using technology is an obstacle that affects teacher performance in the TPD [7].

Web-based learning affects the increasing knowledge of teachers in Spain [56] who are influenced by self-efficacy and beliefs [57]. Teachers with higher self-efficacy and stronger beliefs have better motivation than others [58]. Besides, perceptions of convenience will also affect teachers in using the technology intensively [14].

The obstacle in web-based learning is the lack of skills towards self-regulated learning, [59], while it is crucial in online learning that will add experience to professional knowledge and practice [60].

However, the results of studies comparing the learning models in both online versus face to face on TPD are still limited [18], causing a lack of information for practical needs and decision making [19]. Previous studies comparing online and face to face learning in TPD showed no differences in the level of satisfaction obtained during training, where the score and performance of teachers increased [10] as well as teacher beliefs and teaching skill [11] also the knowledge [56]. However, online interaction influences perceptions of learning, diversity, and comfortable feeling [61] that increase performance [62] and the ability to solve problems [12].

Furthermore, while web-based learning has become a trend for advance, the review of the effect of online learning on TPD is needed. This phenomenon is due to the increased ability of web-based applications, and also the emergence of blended learning as a new hope for online learning [63].

While the influence of web-based learning shows an increase in the proportion of internet use to structural social factors such as age, ethnicity, and gender, the gap between men and women is still quite constant [64] where men are better than women on self-regulated learning [65].

However, it turned out to positive expectation regarding online learning also a factor that influences the success of online learning, so that age and gender, experience, school level the teacher do not become an obstacle to the teacher's pedagogical knowledge [66]. The perceived ease [14] of web-based learning also influences the increase in self-efficacy [67] and motivation (Çakır \& Horzum, 2014), as well as views that are both positive [69], so there is no gender difference in this matter.

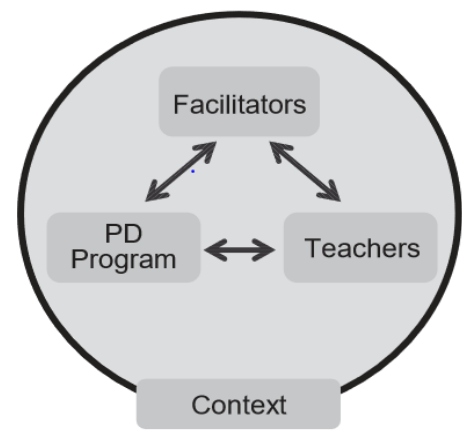

Fig. 1. The element of TPD (Borko) 


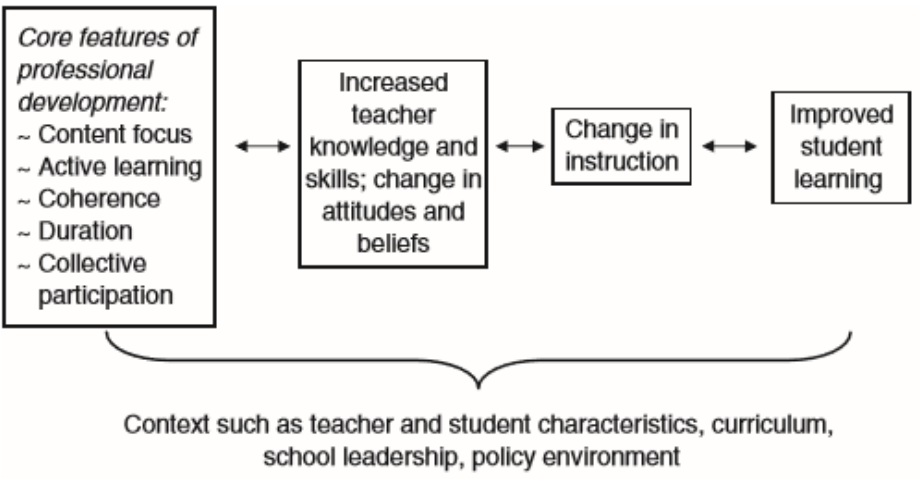

Fig. 2. A Framework for TPD Effectiveness by Desimone (2009).

\subsection{Research question}

The effectiveness of the TPD model in the digital era using web-based learning should be shown by its strong influence on increasing scores in teacher training conducted using online learning rather than the traditional method, which proves that the teacher can achieve learning goals in addition to overcoming digital constraints. This expectation was not obtained from previous studies because teachers have not been able to optimize the features provided, and several other studies show that online learning is no better than traditional learning.

The participants were 427,189 teachers at all levels or 15.82 percent of the approximately 3 million teachers from 34 provinces in Indonesia. Hence, This study contributes to the lack of research using large-scale nationwide samples and can be a reference for research on TPD online.

Therefore, it is appropriate to examine the effects of web-based learning (online and blended learning) in increasing the quality of the national teacher skill test results in line with the goal set by the Indonesian government each year. In perspective of the above, two research questions were formulated by the researcher to address the study purpose:

- What are web-based learning (online and mixed learning) effects on teacher achievement in Indonesia's teacher training program?

- What are the consequences of gender on the attainment of scores of the teacher training program? 


\section{$3 \quad$ Methodology}

\subsection{Design}

This study adopts a quasi-experimental design at a national teacher training program in Indonesia, including pre-test and post-testing with non-equivalent groups. The intervention is digital technology (web-based learning) used in the teacher training model, while the policy is seen as a treatment. There are two groups treatment in online and blended form, and one group is non-treatment, traditional model face to face.

Referring to (White \& Sabarwal, 2014), a quasi-experimental design can be used when a program or policy was viewed as an intervention or treatment, while the group assignment cannot be conducted randomly. Furthermore, it was compared between the intervention and non-intervention groups.

The approach used in the quasi-experimental design in this study is Prepost Nonequivalent Group Design (NEGD). The analysis based on assessing the difference in the amount of change in outcome between the two groups over time, starting with intervention and moving on time. Those taking part in the intervention will be compared [70].

Since after the government's policy of considering extensive area coverage in all the country's provinces and differences in geographical conditions related to internet access as well as budgeting factors, participants could not be assigned to experimental and control groups randomly. The design matches the need for intact training, which fits comfortably into the existing policy programs as it balances the conduct of the quasi-experiment.

\subsection{Participants}

Participants in this study were 427,189 teachers covering all the 34 provinces in all levels of education from kindergarten $(\mathrm{N}=72.046)$, elementary $(\mathrm{N}=222.517)$, middle school $(\mathrm{N}=85.390)$, high school $(\mathrm{N}=27.847)$ and vocational school $(\mathrm{N}=$ 19.419). The 427,189 teacher participants from 34 provinces were obtained randomly because of budgetary considerations, divided into 3 groups, pure online $(\mathrm{N}=63.986)$, face to face $(\mathrm{N}=208.235)$, and hybrid (combination of both) $(\mathrm{N}=154.968)$.

The samples were 115.072 male and 312.117 female divided into groups, i.e., online (19.395 male, 44.591 female), face to face (48.666 male, 159.569 female) and blended (47.011 male, 107.957 female).

\subsection{Instrument}

The ministry of education and culture developed the test, with 30 multiple choice test items, consisting of 10 pedagogics and 20 professional questions conducted at the end of the training program with an allocation of 45 minutes with a total of 30 items. 
For the baseline, it was the result of National level teacher competency test conducted in 2015 (before the training).

The final test was conducted to measure participants' knowledge thoroughly after following the learning process. The assessment used the benchmark reference assessment method. Tests included professional and pedagogical competencies in the knowledge aspect based on program structure set by the ministry of education and culture.

The final test was online after the participants completed the learning activity in all model of training (online, blended, and $\mathrm{f} 2 \mathrm{f}$ ). The final test was carried out in the places of competency test that had been determined by the office education in each province. In the situation (technical error) that the final test could not be online, it was possible for the program to complete the final test offline and the results were processed using a system that has been built by the ministry.

The test of the validity of the questions was done using construct validation and content by experts from Indonesia's Ministry of Education and Culture. The final test was at a prepared place in a situation free from threats to reliability. Such threats include the distance of seating; lamp lighting; calmness of atmosphere; health of participants; confidentiality of test devices; availability of answer sheets; clarity of work instructions; adequacy of time allocation; supervision by the examiner/committee; and anything else that could interfere with the implementation of the test.

\subsection{Procedure}

The researcher was not actively engaged in the management of the instrument in order to avoid experimental bias. The lecturers associated with the administration of the instruments have been adequately trained by the government to assure that instruction is homogeneous across the groups. They were provided detailed explanations before and during the treatment, but not for the participants in all groups.

Based on baseline data, teachers with mastery of the number of 7 competency modules and below are divided into three groups, namely pure online, face to face, and blended or a mix of both. The assignment of participants was carried out without randomization with several considerations, such as the number of module mastery, geographical limitations, and accessibility to the internet. Based on budget constraints, only $15.82 \%$ of teachers were involved in training or 427,189 teachers. The treatment groups conducted learning using a web-based learning model with a learning management system (LMS) applications (online learning and blended learning) while the control group studied without a model.

The training pattern is 60 learning hours@45 minutes, or six weeks using the learning management system (LMS) application, where the module is stored in the server repository and provides video calls as a means of interaction. Through this mode, participants have the flexibility of studying anytime and everywhere and do not have to miss out on their obligations as teachers. Participants can interact with a supervisor/mentor synchronously - learning experiences simultaneously with the use of video calls, the telephone, or live chat — and asynchronously — through learning activities provided electronically offline and online (forums or messages). By utilizing ICT, 
participants fully engage in online learning by accessing and learning teaching materials, working on worksheets, and discussing and sharing knowledge and experiences with other participants as facilitated online by the instructor.

Participants discover respectively online and face-to-face in combination mode (blended learning). The allocated time is the same as for the pattern online, but faceto-face meetings with mentors are held in weeks 1,3 , and 6 in the learning center. The learning centers are set by the education office in each province, coordinating with the ministry of education and culture.

Online learning interactions are carried out independently by utilizing information technology. Learning materials that have been prepared electronically can be used anytime and anywhere. Face-to-face interaction is carried out together with other participants in the learning center as determined by the Education Office in coordination with the Indonesian Ministry of Education and Culture and facilitated by a mentor.

\subsection{Method of data collection}

The scores produced by the teachers ' pre-test and post-test were used as the data accumulated for the fieldwork. Pretest scores were obtained from the results of the 2015 national-level teacher competency test, while the final tests conducted after the 2016 training were used as the score posttest.

\subsection{Data analysis}

Mean rank gain from pretest and posttest has been used to respond to questions of the research. Besides, the null hypotheses adopted for the research were examined using a non-parametric test at the 0.05 significance level. The sample could not normally be distributed and did not meet the criterion of variance homogeneity.

The Kruskal-Wallis test was chosen to test the significance of the three groups and to determine at least one different group. The test stage begins with ranking data (rank-ordered data) and posthoc tests using the Pairwise Mann-Whitney-U tests to determine the groups that are different [71], thus using SPSS 23 software, data were analyzed.

Since the dependent variables were not normally distributed, a non-parametric test was deemed appropriate to analyze the disparity between the treatment's primary effects. Because the study actively engaged pre-testing and post-testing, the quantitative technique used to analyze the hypotheses allows the primary group difference (non-equivalence) using Kruskal Wallis and a post hoc Mann Whitney U test assisted in making comparisons the mean of the groups. If $\mathrm{F}$ is less than 0.05 , the null hypothesis should be rejected. Otherwise, the null hypothesis should not be rejected. In addition to the magnitude of the influence on the differences and correlations the effect size for the mean rank difference using Cohen's d is small (0.2), medium (0.5), and large (0.8). 


\section{$4 \quad$ Result}

\subsection{Comparing teacher's score on groups in every school level of teachers}

In this study, the policy context is on the national level teacher training program, where participants are teachers from all levels. Characteristics of schools, management, and different institutional backgrounds are the considerations for the researcher to analyze based on the school level of teacher background, i.e., kindergarten, elementary, junior high, senior high, and vocational school level. Kruskal Wallis tests were conducted in the ability to examine whether there was a significant difference in the mean rank achievement scores of teachers learned using online and blended form as well as those learned using $\mathrm{f} 2 \mathrm{f}$ process.

The findings in Table 1. showed significant effects of groups on both the pretest and the postest scores at the level of each teacher at $\rho=0,000$, i.e., kindergarten, elementary, junior high, senior high and vocational with small effect size $(d<0,2)$. Consequently, the null hypothesis was rejected, indicating that the mean rank achievement scores of treatment, hybrid, and control groups in teacher training were significantly different.

In all posttest comparisons, Mann-Whitney-U-Tests revealed statistical significance. Consequently, the null hypothesis was rejected, showing that the mean rank achievement scores of treatment, hybrid, and control groups in teacher training were significantly different.

Table 1. Summary of Kruskal Wallis and Post Hoc a Mann Whitney U tests Significance between mean rank experimental and control group scores in teacher training

\begin{tabular}{|c|c|c|c|c|c|c|c|c|c|c|c|}
\hline \multirow{2}{*}{$\begin{array}{l}\text { Pre- } \\
\text { Post } \\
\text { Test }\end{array}$} & \multirow{2}{*}{ Level } & \multirow[t]{2}{*}{$\mathbf{N}$} & \multirow[t]{2}{*}{ Mean } & \multirow[t]{2}{*}{ SD } & \multirow[t]{2}{*}{ Min. } & \multirow{2}{*}{ Max. } & \multirow{2}{*}{$\begin{array}{c}\text { Kruskal } \\
\text { Wallis } \\
\text { test }\end{array}$} & \multirow{2}{*}{$\begin{array}{c}\text { Effect } \\
\text { Size }\end{array}$} & \multicolumn{3}{|c|}{$\begin{array}{c}\text { Post-hoc tests (Mann-Whitney- } \\
\text { U-test) }\end{array}$} \\
\hline & & & & & & & & & $1-2$ & $1-3$ & $2-3$ \\
\hline \multirow{5}{*}{\begin{tabular}{|l|} 
Pretest \\
\\
\\
\\
\end{tabular}} & $\begin{array}{l}\text { Kindergar- } \\
\text { ten }\end{array}$ & 72.016 & 43,81 & 16,35 & 0,0 & 100,0 & 0,000 & 0,011 & $\begin{array}{l}\text { Online }<\mathrm{f} \\
2 \mathrm{f}\end{array}$ & $\begin{array}{l}\text { Online }>\text { Blen } \\
\text { ded }\end{array}$ & $\begin{array}{l}\mathrm{f} 2 \mathrm{f}>\text { Blend } \\
\text { ed }\end{array}$ \\
\hline & $\begin{array}{l}\text { Elemen- } \\
\text { tary }\end{array}$ & 222.517 & 40,99 & 14,51 & 0,0 & 100,0 & 0,000 & 0,006 & $\begin{array}{l}\text { Online }>\mathrm{f} \\
2 \mathrm{f}\end{array}$ & $\begin{array}{l}\text { Online }=\text { Blen } \\
\text { ded }\end{array}$ & $\begin{array}{l}\mathrm{f} 2 \mathrm{f}<\text { Blend } \\
\mathrm{ed}\end{array}$ \\
\hline & $\begin{array}{l}\text { Junior } \\
\text { High }\end{array}$ & 85.390 & 37,75 & 16,96 & 0,0 & 100,0 & 0,000 & 0,014 & $\begin{array}{l}\text { Online }>f \\
2 f\end{array}$ & $\begin{array}{l}\text { Online }>\text { Blen } \\
\text { ded }\end{array}$ & $\begin{array}{l}\mathrm{f} 2 \mathrm{f}>\text { Blend } \\
\text { ed }\end{array}$ \\
\hline & $\begin{array}{l}\text { Senior } \\
\text { High }\end{array}$ & 27.847 & 41,93 & 16,53 & 0,0 & 100,0 & 0,000 & 0,004 & $\begin{array}{l}\text { Online }=f \\
2 \mathrm{f}\end{array}$ & $\begin{array}{l}\text { Online }>\text { Blen } \\
\text { ded }\end{array}$ & $\begin{array}{l}\mathrm{f} 2 \mathrm{f}>\text { Blend } \\
\mathrm{ed}\end{array}$ \\
\hline & Vocational & 19.419 & 39,07 & 16,20 & 0,0 & 100,0 & 0,000 & 0,009 & $\begin{array}{l}\text { Online }>\mathrm{f} \\
2 \mathrm{f}\end{array}$ & $\begin{array}{l}\text { Online }>\text { Blen } \\
\text { ded }\end{array}$ & $\begin{array}{l}f 2 f>\text { Blend } \\
\text { ed }\end{array}$ \\
\hline \multirow[t]{5}{*}{$\begin{array}{l}\text { Post- } \\
\text { test }\end{array}$} & \begin{tabular}{|l|} 
Kindergar- \\
ten
\end{tabular} & 72.016 & 64,39 & 14,44 & 2,5 & 100,0 & 0,000 & 0,013 & $\begin{array}{l}\text { Online }<f \\
2 \mathrm{f}\end{array}$ & $\begin{array}{l}\text { Online }<\text { Blen } \\
\text { ded }\end{array}$ & $\begin{array}{l}\mathrm{f} 2 \mathrm{f}>\text { Blend } \\
\text { ed }\end{array}$ \\
\hline & $\begin{array}{l}\text { Elemen- } \\
\text { tary }\end{array}$ & 222.517 & 49,00 & 15,62 & 0,0 & 100,0 & 0,000 & 0,040 & $\begin{array}{l}\text { Online }>\mathrm{f} \\
2 \mathrm{f}\end{array} \mid$ & $\begin{array}{l}\text { Online }>\text { Blen } \\
\text { ded }\end{array}$ & $\begin{array}{l}\mathrm{f} 2 \mathrm{f}<\text { Blend } \\
\text { ed }\end{array}$ \\
\hline & $\begin{array}{l}\text { Junior } \\
\text { High }\end{array}$ & 85.390 & 56,88 & 14,67 & 0,0 & 100,0 & 0,000 & 0,016 & $\begin{array}{l}\text { Online }>\mathrm{f} \\
2 \mathrm{f}\end{array}$ & $\begin{array}{l}\text { Online }>\text { Blen } \\
\text { ded }\end{array}$ & $\begin{array}{l}\mathrm{f} 2 \mathrm{f}<\mathrm{B} \text { lend } \\
\mathrm{ed}\end{array}$ \\
\hline & $\begin{array}{l}\text { Senior } \\
\text { High }\end{array}$ & 27.847 & 60,94 & 15,11 & 0,0 & 100,0 & 0,000 & 0,053 & $\begin{array}{l}\text { Online }>\mathrm{f} \\
2 \mathrm{f}\end{array}$ & $\begin{array}{l}\text { Online }>\text { Blen } \\
\text { ded }\end{array}$ & $\begin{array}{l}\mathrm{f} 2 \mathrm{f}<\mathrm{Blend} \\
\mathrm{ed}\end{array}$ \\
\hline & Vocational & 19.419 & 65,66 & 16,37 & 0,0 & 100,0 & 0,000 & 0,003 & $\begin{array}{l}\text { Online }>\mathrm{f} \\
2 \mathrm{f}\end{array}$ & $\begin{array}{l}\text { Online }<\text { Blen } \\
\text { ded }\end{array}$ & $\begin{array}{l}\mathrm{f} 2 \mathrm{f}<\mathrm{Blend} \\
\mathrm{ed}\end{array}$ \\
\hline
\end{tabular}


Table 2. indicates that face-to-face groups had a decrease in the mean rank gain in almost all levels except in Kindergarten school level. Whereas in the online group, the decline in mean rank gain occurs in two levels, Kindergarten and Vocational school level. Hence, the blended group had the best performance because increase the meangain at all level, exclude the Senior high school level.

These quasi-experiment had groups that are not equivalent, while the mean-rank pre-test was also different in all groups. It caused difficulties to determine the effect of comparing the achievements on groups. Furthermore, researchers compared groups using data from mean-rank gain achieved from pre to posttest to assure the effectiveness of the treatment at all school level of the teacher.

However, the results obtained through the comparison of mean rank gain between groups at each level are the same as the results mentioned above, as shown in Table 3.

The evidence provided in Table 3 shows that the mean rank of treatment and blended group achievements was significantly higher in each level than the control group. The best teacher performance was shown by blended groups in the kindergarten $(\mathrm{Mg}=2.403,77)$, junior high $(\mathrm{Mg}=1.160,33)$ and vocational $(\mathrm{Mg}=687,15)$ school level, as well as treatment groups in the elementary $(\mathrm{Mg}=24.280,81)$ and senior high school level $(\mathrm{Mg}=1.411,66)$. These findings suggest that web-based learning (online and blended learning) approach is more successful in improving teacher achievement than the $2 \mathrm{f}$ method.

Moreover, it can be concluded that web-based models, namely online and blended learning, are proven to have a better influence than face-to-face classes on teacher achievement. These results indicate that digital constraints are not an obstacle in this policy innovation. Although the selection of participants was not randomly assigned, some studies found this was not significantly affecting the results of the comparison.

Table 2. Mean-rank of Pretes and Posttest Scores of teacher achievement groups in teacher training

\begin{tabular}{|c|c|c|c|c|c|c|c|}
\hline \multirow{3}{*}{$\begin{array}{c}\text { Pre-Post } \\
\text { Test }\end{array}$} & \multirow{3}{*}{ Level } & \multicolumn{6}{|c|}{ Group } \\
\hline & & \multicolumn{2}{|c|}{ Treatment (1) } & \multicolumn{2}{|c|}{ Control (2) } & \multicolumn{2}{|c|}{ Hybrid (3) } \\
\hline & & $S D$ & Mean rank & $S D$ & Mean rank & $S D$ & Mean rank \\
\hline \multirow{5}{*}{ Pretest } & Kindergarten & 11,21 & $34.288,55$ & 15,10 & $36.879,85$ & 12,13 & $30.066,78$ \\
\hline & Elementary & 14,78 & $115.356,61$ & 17,53 & $106.397,23$ & 16,18 & $116.073,55$ \\
\hline & Junior High & 14,53 & $47.001,74$ & 16,31 & $41.433,61$ & 15,46 & $40.279,13$ \\
\hline & Senior High & 17,37 & $14.298,49$ & 19,42 & $14.070,79$ & 15,65 & $13.196,06$ \\
\hline & Vocational & 17,84 & $10.622,31$ & 15,74 & $9.705,36$ & 15,77 & $9.301,24$ \\
\hline \multirow{5}{*}{ Posttest } & Kindergarten & 12,21 & $28.213,39$ & 14,43 & $36.968,00$ & 13,78 & $32.470,55$ \\
\hline & Elementary & 15,91 & $139.637,42$ & 15,48 & $99.166,26$ & 15,07 & $120.361,33$ \\
\hline & Junior High & 14,56 & $47.332,57$ & 16,53 & $39.817,82$ & 13,52 & $41.439,46$ \\
\hline & Senior High & 14,20 & $15.710,15$ & 15,53 & $11.943,30$ & 13,70 & $12.071,67$ \\
\hline & Vocational & 15,15 & $9.577,83$ & 16,54 & $9.303,49$ & 17,53 & $9.988,39$ \\
\hline
\end{tabular}


Paper-Effects of Web-Based Learning and F2F Learning on Teachers Achievement in Teacher Training...

Table 3. Mean rank gain of groups on teacher achievement in a teacher training program

\begin{tabular}{|c|c|c|c|c|c|c|c|}
\hline \multirow{3}{*}{ Level } & \multicolumn{6}{|c|}{ Group } & \multirow{3}{*}{ N Total } \\
\hline & \multicolumn{2}{|c|}{ Treatment (1) } & \multicolumn{2}{|c|}{ Control (2) } & \multicolumn{2}{|c|}{ Hybrid (3) } & \\
\hline & $N$ & Mrank Gain & $N$ & Mrank Gain & $N$ & Mrank Gain & \\
\hline Kindergarten & 3.929 & $-6.075,16$ & 60.371 & 88,15 & 7.716 & $2.403,77$ & 72.016 \\
\hline Elementary & 15.408 & $24.280,81$ & 09.574 & $-7.230,97$ & 97.535 & $4.287,78$ & 222.517 \\
\hline Junior High & 25.892 & 330,83 & 27.954 & $-1.615,79$ & 31.544 & $1.160,33$ & 85.390 \\
\hline Senior High & 14.356 & $1.411,66$ & 5.081 & $-2.127,49$ & 8.410 & $-1.124,39$ & 27.847 \\
\hline \multirow[t]{2}{*}{ Vocational } & 4.401 & $-1.044,48$ & 5.255 & $-401,87$ & 9.763 & 687,15 & 19.419 \\
\hline & 63.986 & & 208.235 & & 54.968 & & 427.189 \\
\hline
\end{tabular}

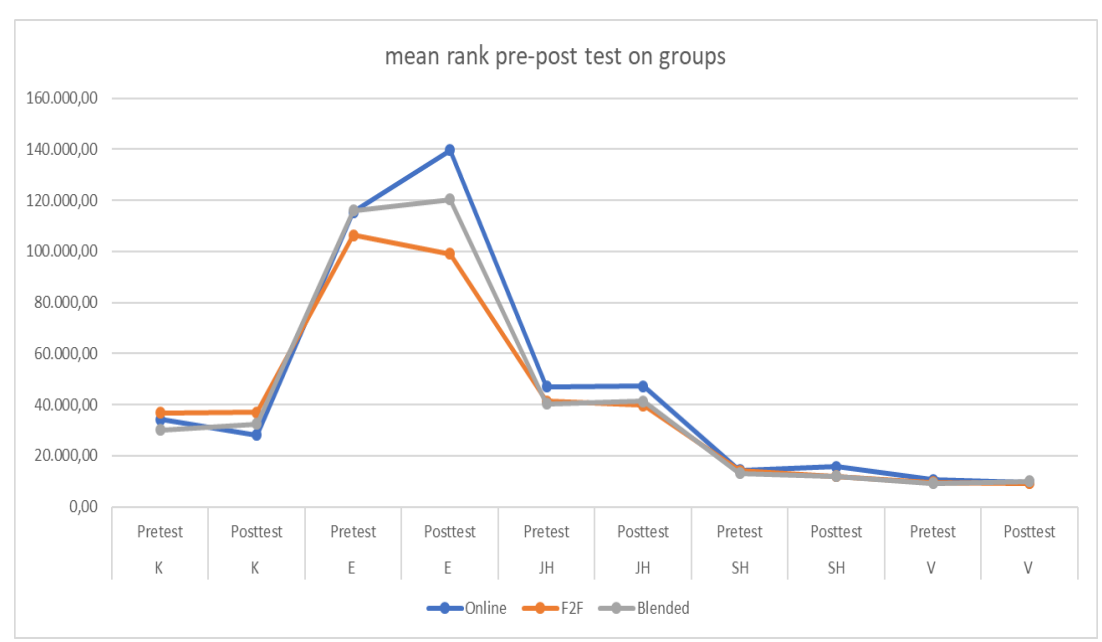

Fig. 3. The mean-rank pre-post test on groups at the teacher school level 


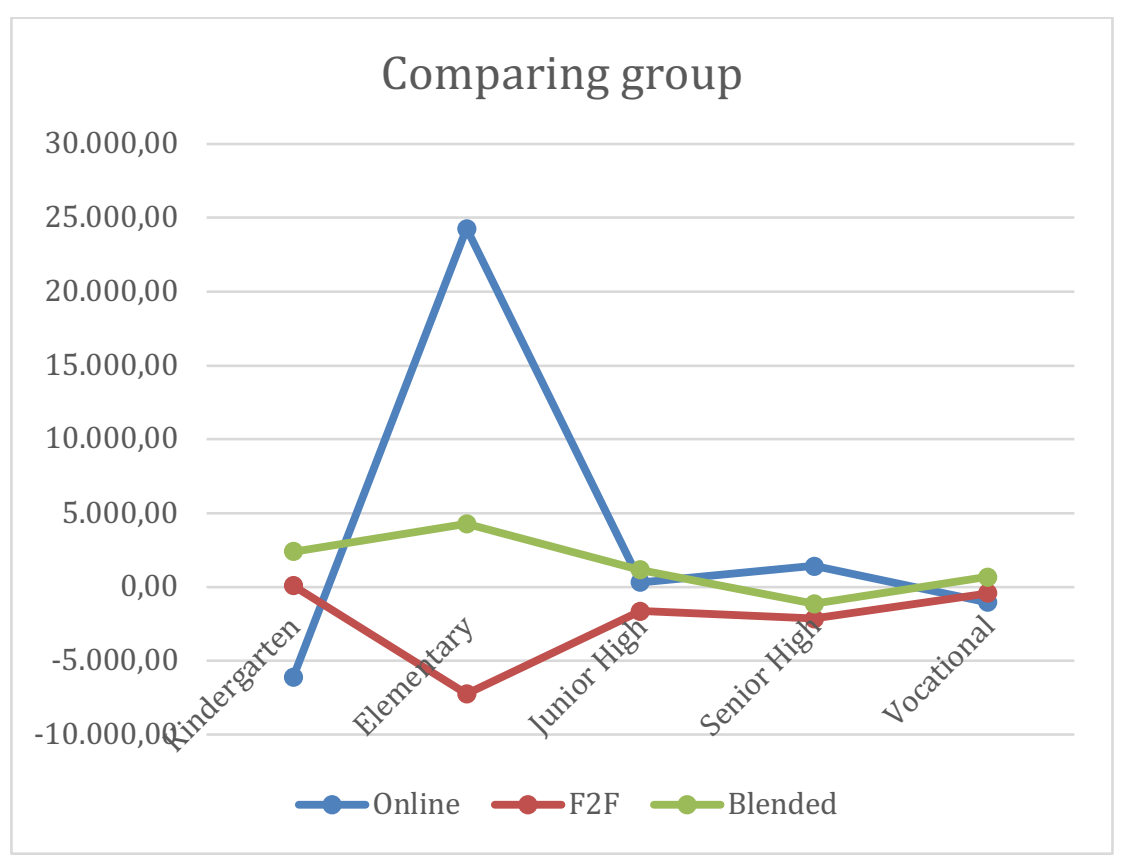

Fig. 4. Comparing mean rank gain on group

\subsection{Comparing teacher's score on groups based on gender}

Gender can be one of the confounding variables that may affect teacher achievement in this training program. Hence, It is necessary to examine the effect of learning based on gender. Furthermore, when exposed to the same treatment conditions, the researchers examined whether gender significantly influenced the achievement of teachers. Table $4 \& 5$ present the results of Kruskal Wallis tests for gender revealing significant effects of the three groups on the teacher's pretest scores and posttest scores in all teachers level $(\alpha<=0,05))$, i.e. kindergarten, elementary, junior high, senior high and vocational with small effect size $(d<0,2)$. Male Pairwise MannWhitney-U-Test revealed the statistical significances that occurred across all comparisons except kindergarten and high school (f2 $\mathrm{f}$ vs. blended). Accordingly, the null hypothesis was rejected indicating that there were significant differences between the mean rank achievement scores of web-based learning versus f2f groups except for the level of teachers in kindergarten and high school (f2 $\mathrm{f}$ versus blended). MannWhitney-U-Tests revealed statistically significant for women in all comparisons except high school (f2f vs. blended) and vocational school (online vs. f2f) levels. Therefore, the null hypothesis was rejected implying that there were significant differences between the mean rank achievement scores of teacher training groups except for those high school (f2 f vs. blended) and vocational school (online vs. blended). 
Table 4. Summary of Kruskal Wallis and Post Hoc a Mann Whitney U tests of Significance between the mean rank experimental and control group scores of gender in the teacher training program

\begin{tabular}{|c|c|c|c|c|c|c|c|c|c|c|c|}
\hline \multirow[t]{2}{*}{ Male } & \multirow[t]{2}{*}{ Level } & \multirow[t]{2}{*}{$\mathbf{N}$} & \multirow[t]{2}{*}{ Mean } & \multirow[t]{2}{*}{ SD } & \multirow[t]{2}{*}{ Min. } & \multirow{2}{*}{ Max. } & \multirow{2}{*}{$\begin{array}{c}\text { Kruskal } \\
\text { Wallis } \\
\text { test }\end{array}$} & \multirow{2}{*}{$\begin{array}{c}\text { Effect } \\
\text { Size }\end{array}$} & \multicolumn{3}{|c|}{\begin{tabular}{|c} 
Post-hoc tests (Mann-Whitney- \\
U-test)
\end{tabular}} \\
\hline & & & & & & & & & $1-2$ & $1-3$ & $2-3$ \\
\hline \multirow[t]{6}{*}{ Pretest } & $\begin{array}{l}\text { Kinder- } \\
\text { garten }\end{array}$ & 983 & 42,69 & 16,42 & 0,0 & 92,9 & 0,000 & 0,016 & $\begin{array}{l}\text { Online }=\mathrm{f} \\
2 \mathrm{f}\end{array}$ & $\begin{array}{l}\text { Online=Blen } \\
\text { ded }\end{array}$ & $\begin{array}{l}\mathrm{f} 2 \mathrm{f}>\text { Blend } \\
\text { ed }\end{array}$ \\
\hline & $\begin{array}{l}\text { Elemen- } \\
\text { tary }\end{array}$ & 65.508 & 41,38 & 13,96 & 0,0 & 100,0 & 0,000 & 0,001 & $\begin{array}{l}\text { Online }>f \\
2 f\end{array}$ & $\begin{array}{l}\text { Online }>\text { Blen } \\
\text { ded }\end{array}$ & $\begin{array}{l}\mathrm{f} 2 \mathrm{f}<\mathrm{Blend} \\
\mathrm{ed}\end{array}$ \\
\hline & \begin{tabular}{|l} 
Junior \\
High \\
\end{tabular} & 29.994 & 37,88 & 16,79 & 0,0 & 100,0 & 0,000 & 0,020 & $\begin{array}{l}\text { Online }>f \\
2 f\end{array}$ & $\begin{array}{l}\text { Online>Blen } \\
\text { ded }\end{array}$ & $\begin{array}{l}\mathrm{f} 2 \mathrm{f}<\text { Blend } \\
\mathrm{ed}\end{array}$ \\
\hline & $\begin{array}{l}\text { Senior } \\
\text { High } \\
\end{array}$ & 9.437 & 42,61 & 16,77 & 0,0 & 100,0 & 0,000 & 0,008 & $\begin{array}{l}\text { Online }>f \\
2 f\end{array}$ & $\begin{array}{l}\text { Online }>\text { Blen } \\
\text { ded }\end{array}$ & $\begin{array}{l}\mathrm{f} 2 \mathrm{f}>\text { Blend } \\
\mathrm{ed}\end{array}$ \\
\hline & $\begin{array}{l}\text { Vocation- } \\
\text { al }\end{array}$ & 9.150 & 38,98 & 16,00 & 0,0 & 100,0 & 0,000 & 0,006 & $\begin{array}{l}\text { Online }>f \\
2 \mathrm{f}\end{array}$ & $\begin{array}{l}\text { Online }>\text { Blen } \\
\text { ded }\end{array}$ & $\begin{array}{l}\mathrm{f} 2 \mathrm{f}=\text { Blend } \\
\text { ed }\end{array}$ \\
\hline & & $\begin{array}{c}115.07 \\
2\end{array}$ & & & & & & & & & \\
\hline \multirow[t]{6}{*}{\begin{tabular}{|l} 
Post- \\
test
\end{tabular}} & $\begin{array}{l}\begin{array}{l}\text { Kinder- } \\
\text { garten }\end{array} \\
\end{array}$ & 983 & 61,86 & 14,96 & 12,5 & 100,0 & 0,022 & 0,008 & $\begin{array}{l}\text { Online }=\mathrm{f} \\
2 \mathrm{f}\end{array}$ & $\begin{array}{l}\text { Online=Blen } \\
\text { ded }\end{array}$ & $\begin{array}{l}\mathrm{f} 2 \mathrm{f}>\mathrm{Blend} \\
\mathrm{ed}\end{array}$ \\
\hline & $\begin{array}{l}\text { Elemen- } \\
\text { tary }\end{array}$ & 65.508 & 49,44 & 15,15 & 0,0 & 100,0 & 0,000 & 0,034 & $\begin{array}{l}\text { Online }>f \\
2 \mathrm{f}\end{array}$ & $\begin{array}{l}\text { Online }>\text { Blen } \\
\text { ded }\end{array}$ & $\begin{array}{l}\mathrm{f} 2 \mathrm{f}<\mathrm{Blend} \\
\mathrm{ed}\end{array}$ \\
\hline & \begin{tabular}{|l} 
Junior \\
High
\end{tabular} & 29.994 & 55,57 & 14,56 & 0,0 & 100,0 & 0,000 & 0,018 & $\begin{array}{l}\text { Online }>\mathrm{f} \\
2 \mathrm{f}\end{array}$ & $\begin{array}{l}\text { Online }>\text { Blen } \\
\text { ded }\end{array}$ & $\begin{array}{l}\mathrm{f} 2 \mathrm{f}<\text { Blend } \\
\mathrm{ed}\end{array}$ \\
\hline & \begin{tabular}{|l|} 
Senior \\
High
\end{tabular} & 9.437 & 59,24 & 15,04 & 2,5 & 100,0 & 0,000 & 0,045 & $\begin{array}{l}\text { Online }>\mathrm{f} \\
2 \mathrm{f}\end{array}$ & $\begin{array}{l}\text { Online }>\text { Blen } \\
\text { ded }\end{array}$ & $\begin{array}{l}\mathrm{f} 2 \mathrm{f}=\mathrm{Blend} \\
\mathrm{ed}\end{array}$ \\
\hline & $\begin{array}{l}\text { Vocation- } \\
\text { al }\end{array}$ & 9.150 & 65,18 & 17,18 & 0,0 & 100,0 & 0,000 & 0,003 & $\begin{array}{l}\text { Online }>\mathrm{f} \\
2 \mathrm{f}\end{array}$ & $\begin{array}{l}\text { Online=Blen } \\
\text { ded }\end{array}$ & $\begin{array}{l}\mathrm{f} 2 \mathrm{f}<\text { Blend } \\
\mathrm{ed}\end{array}$ \\
\hline & & $\begin{array}{c}115.07 \\
2\end{array}$ & & & & & & & & & \\
\hline
\end{tabular}

\begin{tabular}{|c|c|c|c|c|c|c|c|c|c|c|c|}
\hline \multirow{2}{*}{$\begin{array}{l}\mathrm{Fe}- \\
\text { male }\end{array}$} & \multirow[t]{2}{*}{ Level } & \multirow[t]{2}{*}{$\mathbf{N}$} & \multirow[t]{2}{*}{ Mean } & \multirow[t]{2}{*}{ SD } & \multirow[t]{2}{*}{ Min. } & \multirow[t]{2}{*}{ Max. } & \multirow{2}{*}{$\begin{array}{c}\text { Kruskal } \\
\text { Wallis } \\
\text { test }\end{array}$} & \multirow{2}{*}{$\begin{array}{l}\text { Ef- } \\
\text { fect } \\
\text { Size } \\
\end{array}$} & \multicolumn{3}{|c|}{$\begin{array}{l}\text { Post-hoc tests (Mann-Whitney- } \\
\text { U-test) }\end{array}$} \\
\hline & & & & & & & & & \begin{tabular}{|c|}
$1-2$ \\
\end{tabular} & $1-3$ & $2-3$ \\
\hline \multirow[t]{6}{*}{$\begin{array}{l}\text { Pre- } \\
\text { test }\end{array}$} & $\begin{array}{l}\text { Kindergar- } \\
\text { ten }\end{array}$ & 71.033 & 43,82 & 16,35 & 0,0 & 100,0 & 0,001 & 0,011 & $\begin{array}{l}\text { Online }<\mathrm{f} \\
2 \mathrm{f}\end{array}$ & $\begin{array}{l}\text { Online>Blen } \\
\text { ded }\end{array}$ & $\begin{array}{l}f 2 f>\text { Blend } \\
\text { ed }\end{array}$ \\
\hline & Elementary & 157.009 & 40,83 & 14,73 & 0,0 & 100,0 & 0,000 & 0,009 & $\begin{array}{l}\text { Online }>\mathrm{f} \\
2 \mathrm{f}\end{array}$ & $\begin{array}{l}\text { Online }<\text { Blen } \\
\text { ded }\end{array}$ & $\begin{array}{l}\mathrm{f} 2 \mathrm{f}<\text { Blend } \\
\mathrm{ed}\end{array}$ \\
\hline & Junior High & 55.396 & 37,68 & 17,06 & 0,0 & 100,0 & 0,000 & 0,011 & $\begin{array}{l}\text { Online }>\mathrm{f} \\
2 \mathrm{f}\end{array}$ & $\begin{array}{l}\text { Online }>\text { Blen } \\
\text { ded }\end{array}$ & $\begin{array}{l}\text { f2f }>\text { Blend } \\
\text { ed }\end{array}$ \\
\hline & Senior High & 18.410 & 41,57 & 16,40 & 0,0 & 100,0 & 0,000 & 0,002 & $\begin{array}{l}\text { Online }=\mathrm{f} \\
2 \mathrm{f}\end{array}$ & $\begin{array}{l}\text { Online }>\text { Blen } \\
\text { ded }\end{array}$ & $\begin{array}{l}f 2 f>\text { Blend } \\
\text { ed }\end{array}$ \\
\hline & Vocational & 10.269 & 39,15 & 16,37 & 0,0 & 100,0 & 0,000 & 0,014 & $\begin{array}{l}\text { Online }>\mathrm{f} \\
2 \mathrm{f}\end{array}$ & $\begin{array}{l}\text { Online }>\text { Blen } \\
\text { ded }\end{array}$ & $\begin{array}{l}f 2 f>\text { Blend } \\
\text { ed }\end{array}$ \\
\hline & & 312.117 & & & & & & & & & \\
\hline \multirow[t]{4}{*}{$\begin{array}{l}\text { Post- } \\
\text { test }\end{array}$} & \begin{tabular}{|l} 
Kindergar- \\
ten
\end{tabular} & 71.033 & 64,42 & 14,43 & 2,5 & 100,0 & 0,000 & 0,013 & $\begin{array}{l}\text { Online }<\mathrm{f} \\
2 \mathrm{f}\end{array}$ & $\begin{array}{l}\text { Online }<\text { Blen } \\
\text { ded }\end{array}$ & $\begin{array}{l}\text { f2 } \mathrm{f}>\mathrm{Blend} \\
\mathrm{ed}\end{array}$ \\
\hline & Elementary & 157.009 & 48,82 & 15,81 & 0,0 & 100,0 & 0,000 & 0,043 & $\begin{array}{l}\text { Online }>\mathrm{f} \\
2 \mathrm{f}\end{array}$ & $\begin{array}{l}\text { Online }>\text { Blen } \\
\text { ded }\end{array}$ & $\begin{array}{l}\mathrm{f} 2 \mathrm{f}<\text { Blend } \\
\mathrm{ed}\end{array}$ \\
\hline & Junior High & 55.396 & 57,59 & 14,69 & 0,0 & 100,0 & 0,000 & 0,015 & $\begin{array}{l}\text { Online }>\mathrm{f} \\
2 \mathrm{f}\end{array}$ & $\begin{array}{l}\text { Online>Blen } \\
\text { ded }\end{array}$ & $\begin{array}{l}\mathrm{f} 2 \mathrm{f}<\mathrm{Blend} \\
\mathrm{ed}\end{array}$ \\
\hline & Senior High & 18.410 & 61,81 & 15,08 & 0,0 & 100,0 & 0,000 & 0,055 & Online $>\mathrm{f}$ & Online $>$ Blen & $\mathrm{f} 2 \mathrm{f}=\mathrm{B}$ lend \\
\hline
\end{tabular}




\begin{tabular}{|l|l|l|l|l|l|l|l|l|l|l|l|}
\hline & & & & & & & & & $2 \mathrm{f}$ & ded & ed \\
\hline & Vocational & 10.269 & 65,91 & 15,61 & 0,0 & 100,0 & 0,000 & 0,004 & $\begin{array}{l}\text { Online=f } \\
2 \mathrm{f}\end{array}$ & $\begin{array}{l}\text { Online }<\mathrm{B} \text { len } \\
\mathrm{f} 2 \mathrm{f}<\mathrm{Blend} \\
\mathrm{ed}\end{array}$ \\
\hline & & 312.117 & & & & & & & & & \\
\hline
\end{tabular}

However, it turns out that the test produces the same result related to the effect shown by the comparison of group achievements in every school level based on gender. The findings show that face to face has the lowest, while the blended was the highest achievement resulted from kindergarten, junior high, and vocational school level.

Table 5 show that male teachers learned using online learning achieved the best mean rank gain in the elementary level $(\mathrm{Mg}=7.234,08)$ as well as in the senior high school level $(\mathrm{Mg}=400,09)$, while teachers learned that using blended learning achieved the best performance in the kindergarten $(\mathrm{Mg}=40,75)$, junior high $(\mathrm{Mg}=384,20)$ and vocational school level $(\mathrm{Mg}=179,01)$. In the kindergarten $(\mathrm{Mg}=2,363,87)$, junior high $(727,54)$ and vocational school level $(\mathrm{Mg}=529,79)$, female teachers exposed to the same treatment conditions had the highest mean rank gain for blended learning, while online learning had the best gain in primary $(\mathrm{Mg}=17,079,12)$ and secondary $(\mathrm{Mg}=968,67)$ levels.

Interestingly, even though gender produces gains increased that tend to be the same in all level, the mean rank achievement obtained by women is higher than that of men. The female teacher's practice web-based learning seemed to have significantly higher than the male.

These findings lead to convincing that the effect of web-based learning on the teacher achievement on teacher training scores are significant. Furthermore, this result reveals new insight of gender on web-based learning on TPD, whereas different acquisition trends than the previous one in which men were no better than women.

Table 5. Mean rank of pre-test and post-test scores of gender effects on teacher achievement using online and mixed learning models (male \& female)

\begin{tabular}{|c|l|c|c|c|c|c|c|}
\hline \multirow{2}{*}{ Male } & \multirow{2}{*}{ Level } & \multicolumn{6}{|c|}{ Group } \\
\cline { 3 - 8 } & & \multicolumn{2}{|c|}{ Treatment (1) } & \multicolumn{2}{c|}{ Control (2) } & \multicolumn{2}{c|}{ Hybrid (3) } \\
\cline { 3 - 8 } & & SD & Mean rank & SD & Mean rank & SD & Mean rank \\
\hline \multirow{5}{*}{ Pretest } & Kindergarten & 9,75 & 496,39 & 14,73 & 505,90 & 14,65 & 396,45 \\
\cline { 2 - 9 } & Elementary & 14,05 & $34.145,25$ & 15,96 & $32.146,95$ & 15,35 & $33.220,19$ \\
\cline { 2 - 8 } & Junior High & 13,73 & $16.885,92$ & 16,35 & $14.519,04$ & 14,40 & $13.930,56$ \\
\cline { 2 - 9 } & Senior High & 17,74 & $4.914,32$ & 19,24 & $4.760,89$ & 15,45 & $4.362,48$ \\
\cline { 2 - 8 } & Vocational & 18,37 & $5.042,59$ & 14,99 & $4.457,96$ & 15,14 & $4.501,81$ \\
\hline \multirow{5}{*}{ Posttest } & Kindergarten & 11,14 & 434,20 & 15,00 & 503,21 & 14,83 & 437,20 \\
\cline { 2 - 8 } & Elementary & 15,87 & $41.379,33$ & 15,35 & $29.616,42$ & 15,16 & $34.928,54$ \\
\cline { 2 - 8 } & Junior High & 13,61 & $16.815,57$ & 15,81 & $14.183,88$ & 13,58 & $14.314,76$ \\
\cline { 2 - 8 } & Senior High & 14,24 & $5.314,41$ & 15,22 & $4.113,50$ & 13,58 & $4.202,78$ \\
\cline { 2 - 8 } & Vocational & 14,68 & $4.631,00$ & 17,00 & $4.367,29$ & 18,28 & $4.680,82$ \\
\hline
\end{tabular}




\begin{tabular}{|c|c|c|c|c|c|c|c|}
\hline \multirow[t]{3}{*}{ Female } & \multirow[t]{3}{*}{ Level } & \multicolumn{6}{|c|}{ Group } \\
\hline & & \multicolumn{2}{|c|}{ Treatment (1) } & \multicolumn{2}{|c|}{ Control (2) } & \multicolumn{2}{|c|}{ Hybrid (3) } \\
\hline & & SD & Mean rank & SD & Mean rank & $\mathrm{SD}$ & Mean rank \\
\hline \multirow{5}{*}{ Pretest } & Kindergarten & 11,22 & $33.792,56$ & 15,10 & $36.374,19$ & 12,09 & $29.677,76$ \\
\hline & Elementary & 13,42 & $81.205,73$ & 17,84 & $74.249,79$ & 15,62 & $82.843,23$ \\
\hline & Junior High & 14,34 & $30.144,81$ & 16,68 & $26.916,08$ & 14,93 & $26.336,72$ \\
\hline & Senior High & 17,18 & $9.402,18$ & 19,52 & $9.263,75$ & 15,75 & $8.834,85$ \\
\hline & Vocational & 17,56 & $5.593,23$ & 16,57 & $5.284,70$ & 16,21 & $4.789,79$ \\
\hline \multirow{5}{*}{ Posttest } & Kindergarten & 12,22 & $27.780,55$ & 14,42 & $36.464,92$ & 13,77 & $32.041,63$ \\
\hline & Elementary & 15,70 & $98.284,85$ & 15,88 & $69.548,52$ & 15,47 & $85.424,15$ \\
\hline & Junior High & 13,65 & $30.485,71$ & 16,63 & $25.714,74$ & 13,53 & $27.064,26$ \\
\hline & Senior High & 14,14 & $10.370,85$ & 15,70 & $7.923,17$ & 13,75 & $7.885,30$ \\
\hline & Vocational & 15,37 & $4.966,09$ & 15,97 & $4.962,86$ & 16,74 & $5.319,58$ \\
\hline
\end{tabular}

Table 6. Mean rank gain of effects of gender on teacher achievement in the teacher training program

\begin{tabular}{|c|c|c|c|c|c|c|c|c|}
\hline \multirow{3}{*}{ Gender } & \multirow{3}{*}{ Level } & \multicolumn{6}{|c|}{ Group } & \multirow[t]{3}{*}{ N Total } \\
\hline & & \multicolumn{2}{|c|}{ Treatment (1) } & \multicolumn{2}{|c|}{ Control (2) } & \multicolumn{2}{|c|}{ Hybrid (3) } & \\
\hline & & $N$ & Mrank Gain & $N$ & Mrank Gain & $N$ & Mrank Gain & \\
\hline \multirow{5}{*}{ Male } & Kindergarten & 44 & $-62,19$ & 818 & $-2,69$ & 121 & 40,75 & 983 \\
\hline & \begin{tabular}{|l|} 
Elementary \\
\end{tabular} & 4.582 & $7.234,08$ & 32.374 & $-2.530,53$ & 28.552 & $1.708,35$ & 65.508 \\
\hline & \begin{tabular}{|l|} 
Junior High \\
\end{tabular} & 8.738 & $-70,35$ & 10.498 & $-335,16$ & 10.758 & 384,20 & 29.994 \\
\hline & \begin{tabular}{|l} 
Senior High \\
\end{tabular} & 4.554 & 400,09 & 2.137 & $-647,39$ & 2.746 & $-159,70$ & 9.437 \\
\hline & Vocational & 1.477 & $-411,59$ & 2.839 & $-90,67$ & 4.834 & 179,01 & 9.150 \\
\hline Subtotal & & 19.395 & & 48.666 & & 47.011 & & 115.072 \\
\hline \multirow{5}{*}{ Female } & Kindergarten & 3.885 & $-6.012,01$ & 59.553 & 90,73 & 7.595 & $2.363,87$ & 71.033 \\
\hline & \begin{tabular}{|l|} 
Elementary \\
\end{tabular} & 10.826 & $17.079,12$ & 77.200 & $-4.701,27$ & 68.983 & $2.580,92$ & 157.009 \\
\hline & Junior High & 17.154 & 340,90 & 17.456 & $-1.201,34$ & 20.786 & 727,54 & 55.396 \\
\hline & Senior High & 9.802 & 968,67 & 2.944 & $-1.340,58$ & 5.664 & $-949,55$ & 18.410 \\
\hline & Vocational & 2.924 & $-627,14$ & 2.416 & $-321,84$ & 4.929 & 529,79 & 10.269 \\
\hline Subtotal & & 44.591 & & 159.569 & & 107.957 & & 312.117 \\
\hline TOTAL & & 63.986 & & 208.235 & & 54.968 & & 427.189 \\
\hline
\end{tabular}

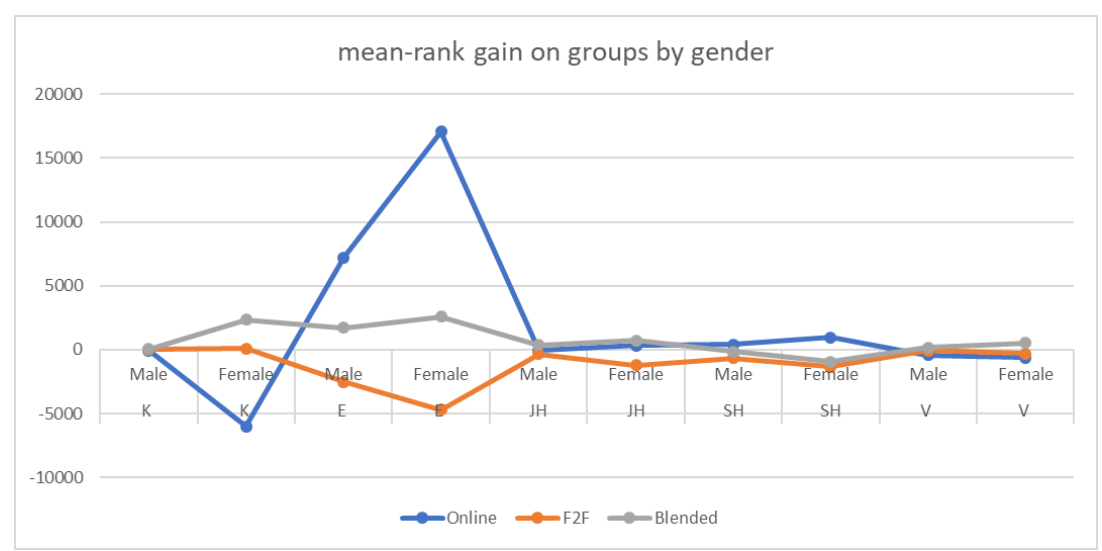

Fig. 5. The mean-rank gain on groups at the teacher school level based on gender 


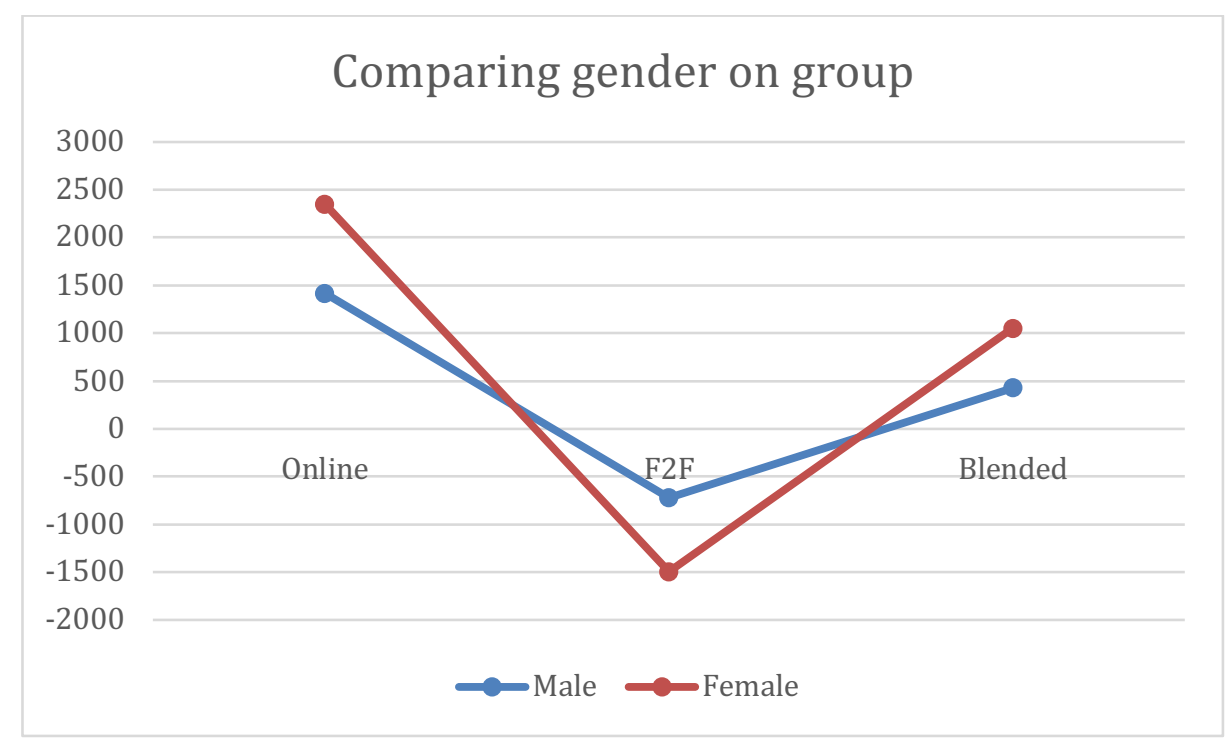

Fig. 6. Comparing mean rank gain of gender on group

\section{Discussion}

There was a statistically significant difference between the main effect of the online and blended learning model and the f2f method. The result shows that webbased learning (online and blended learning) is more effective than $\mathrm{f} 2 \mathrm{f}$ in improving teacher achievement in teacher training. These findings contrast with [10], which revealed that there were no differences in the posttest scores the teacher earned between groups and the study [11] found that there were no significant differences between online and face-to-face teacher knowledge. However, this finding is in line with [46] who revealed that the experimental group demonstrated a much higher level of knowledge than face-to-face, although self-efficacy and level of learning satisfaction were almost the same. This finding implies that digital constraint was not an obstacle for the teacher in Indonesia, where the policy innovation in teacher training is adequately implemented. Hence, this finding was a progressive enough from the previous study of implementing technology innovation in education in Indonesia by [16], where assume that ICT innovation is considered to be the key to education transforming, yet many IT projects are far from sufficient.

Furthermore, the effect of teacher achievement can be attributable to the aspect of the variables that are not available in this study. Connectedness virtually is one of the distinguishing factors for online learning and traditional learning [61]. Furthermore, self-directed learning as a significant aspect of professional development for teachers encourages higher levels of commitment with professional learning [60] reflects the thought that teachers develop their learning demands and direct their learning accordingly [72] influences teaching activity and the development of training in classrooms [73]. 
Web-based learning proved to have positive effects on learning, such as helping to develop thinking skills, improving activities and learning opportunities, increasing scores and achievement [54], improving knowledge [56] also facilitating higher-level learning better [74].

Moreover, blended learning appears to be better than online learning, where the best performance from the kindergarten, junior high, and vocational levels are from the blended group, while face to face became the worst. Hence, blended learning emerged as a new trend in e-learning [40] proved to be quite promising for innovative TPD in Indonesia.

Furthermore, the result from comparison groups based on gender strengthens the findings above, where show the same effect in every school level of the teacher. Interestingly, women are better than men. These findings affirm that there is no discrepancy in the performance of male and female teachers in teacher training, where in contrast with the result of [65] who found that male teachers were statistically far more ready than female teachers. However, these findings are in line with [9] who showed that the blended delivery produced better posttest scores for women and [75] who found that girls groups scored higher compared to all boys groups, even though men tend to have more positive behavior towards technology adoption [76]. These findings provide disagreement for the potential digital divide in women [77] where men are considered to have higher competencies in technology [78]. Indeed, there are differences in gender [79] towards the acceptance of online learning [80] but with reversed conditions and will be a further discussion of the digital divide related to gender.

\section{Conclusion}

Promoting the reform of teacher professional development (TPD) in the digital era using web-based learning (online and blended learning) appears to be a great innovation in improving teachers skills using technology through computers and Internet networks.

The finding leads to the policy innovation bringing to the TPD model through teacher training is successful enough. Even though there were variables attributable to the effect that is not examined in this paper, but web-based learning influences teacher achievement in the teacher training program in Indonesia better than face to face method.

Blended learning emerged as a new trend in e-learning [40] can be quite promising for innovative TPD in Indonesia. Interestingly, these results indicate the pattern of the teacher training model to the school level, where there seems to be relevance between the school levels and the appropriate teacher training model, while further evaluation is warranted. This finding indicates that digital constraints are not an obstacle for the teacher in Indonesia. Moreover, women perform better than men.

This study fills a lack of reference to research on the comparison of the TPD model through teacher training with a large scale sample size. 


\section{$7 \quad$ Limitation \& Recommendation}

This research is close to the study of impact evaluations for the implementation of programs and policies that are commonly carried out in developing countries with various approaches and methods to get feedback for the development of program implementation in the future. This study evaluates the short-term policy carried out at the beginning of the program implementation to test the effectiveness of the teacher training model through a comparison of teacher achievement in different models before and after the treatment.

However, the effect resulted from the web-based learning can be attributable to aspects that are not available in this study. Referring to the TPD research framework used by Borko (2004) as reviewed in Chapter 2, this study entered the first phase, which evaluates at the influence of TPD on teachers as learners. However, the score's gain is the only variable used to measure the teacher's performance. Others that can influence are self-efficacy, beliefs, and motivation, but not provided in this study, as well as connectivity that is important for online learning study. What is also essential in this study, but not provided here is the teacher experience that significantly affects their performance.

A large number of participants concerning the implementation of policies in the country has become an advantage in this paper. The large sample size is related to external validity and ability in terms of generalization so that it can be a reference for similar research in the future. The scope of research is excluded from pre-service and student of teacher education, which conducted in higher education. The researcher viewed that in-service training for teachers has a particular background and characteristics. Hence this study may enrich of TPD research in the comparativeness teacher training model and fill the lack of large sample size.

The quantitative and qualitative studies to determine the self-efficacy, confidence, and motivation to determine the behavior of internet access and use for teachers in Indonesia is necessarily in the future. Moreover, based on the results, indicate that relevance between the appropriate teacher training model and the teacher school level need further discussion. Moreover, the digital divide related to the gender on webbased learning or online learning will be an interesting issue for the next study.

\section{Acknowledgement}

The researchers are grateful to The Master and Doctoral Program in Leadership and Policy Innovation, Graduate School of Universitas Gadjah Mada for the grant to support this paper. Also, acknowledgment is given to The Directorate General Teachers and Education Personnel, Ministry of Education and Culture of Indonesia for approval in accessing Teacher Training Program "Guru Pembelajar." 


\section{$9 \quad$ References}

[1] P. Twining, J. Raffaghelli, P. Albion, and D. Knezek, "Moving education into the digital age: The contribution of teachers' professional development," J. Comput. Assist. Learn., vol. 29, no. 5, pp. 426-437, 2013. https://doi.org/10.1111/jcal.12031

[2] C. Brooks and S. Gibson, "Professional Learning in a Digital Age.," Can. J. Learn. Technol., vol. 38 , no. 2, p. 17, 2012.

[3] E. A. S. Neira, J. Salinas, and B. de B. Crosetti, "Emerging Technologies (ETs) in education: A systematic review of the literature published between 2006 and 2016," Int. J. Emerg. Technol. Learn., vol. 12, no. 5, pp. 128-149, 2017. https://doi.org/10.3991/ijet.v12i05.6939

[4] M. S. Bates, L. Phalen, and C. G. Moran, "If you build it, will they reflect? Examining teachers' use of an online video-based learning website," Teach. Teach. Educ., vol. 58, pp. 17-27, 2016. https://doi.org/10.1016/j.tate.2016.04.004

[5] L. S. Shulman and J. H. Shulman, "How and what teachers learn: A shifting perspective," J. Curric. Stud., vol. 36, no. 2, pp. 257-271, 2004. https://doi.org/10.1080/0022027032000148298

[6] A.-B. Sánchez-García, J.-J. M. Marcos, H. GuanLin, and J. P. Escribano, "Teacher Development and ICT: The Effectiveness of a Training Program for In-service School Teachers," Procedia - Soc. Behav. Sci., vol. 92, no. Lumen, pp. 529-534, 2013. https://doi.org/10.1016/j.sbspro.2013.08.713

[7] S. Mohammadyari and H. Singh, "Computers \& Education Understanding the effect of elearning on individual performance: The role of digital literacy," Comput. Educ., vol. 82, pp. 11-25, 2015. https://doi.org/10.1016/j.compedu.2014.10.025

[8] J. Underwood, “The Impact of Digital Technology,” 2009.

[9] I. Y. Kazu and M. Demirkol, "Effect of Blended Learning Environment Model on High School Students' Academic Achievement," Turkish Online J. Educ. Technol., vol. 13, no. 1, pp. 78-87, 2014.

[10] J. B. Fisher, J. B. Schumaker, J. Culbertson, and D. D. Deshler, "Effects of a Computerized Professional Development Program on Teacher and Student Outcomes," J. Teach. Educ., vol. 61, no. 4, pp. 302-312, 2010. https://doi.org/10.1177/0022487110369556

[11] B. Fishman et al., "Comparing the Impact of Online and Face-to-Face Professional Development in the Context of Curriculum Implementation," J. Teach. Educ., vol. 64, no. 5, pp. 426-438, 2013.

[12] D. C. Webb, H. Nickerson, and J. B. Bush, "A Comparative Analysis of Online and Faceto-Face Professional Development Models for CS Education," in Proceedings of the 2017 ACM SIGCSE Technical Symposium on Computer Science Education - SIGCSE '17, 2017, pp. 621-626. https://doi.org/10.1145/3017680.3017784

[13] L. J. Collins and X. Liang, "Examining High Quality Online Teacher Professional Development: Teachers' Voices,” Int. J. Teach. Leadersh., vol. 18, no. 1, pp. 18-34, 2015.

[14] M. Kalogiannakis and S. Papadakis, "Evaluating pre-service kindergarten teachers' intention to adopt and use tablets into teaching practice for natural sciences," Int. J. Mob. Learn. Organ., vol. 13, no. 1, p. 113, 2018. https://doi.org/10.1504/ijmlo.2019.10016617

[15] F. Miao, S. Mishra, and R. McGreal, Open Educational Resources : Policy, Costs and, no. May 2016. UNESCO, 2017. 
[16] M. Q. Huda and H. Hussin, "Evaluation model of Information Technology innovation effectiveness case of higher education institutions in Indonesia," 2016 Int. Conf. Informatics Comput., no. Icic, pp. 221-226, 2016. https://doi.org/10.1109/iac.2016.7905719

[17] M. M. Abbad and F. N. Jaber, "Evaluating e-learning systems: An empirical investigation on students' perception in higher education area," Int. J. Emerg. Technol. Learn., vol. 9, no. 4, pp. 27-34, 2014. https://doi.org/10.3991/ijet.v9i4.3480

[18] D. Lubans, A. Lloyd, J. Bowe, J. Gore, M. Smith, and H. Ellis, "Effects of professional development on the quality of teaching: Results from a randomised controlled trial of Quality Teaching Rounds," Teach. Teach. Educ., vol. 68, pp. 99-113, 2017. https://doi.org/10.1016/j.tate.2017.08.007

[19] K. Greene and W. Hale, "The State of 21 st Century Learning in the K-12 World of the United States: Online and Blended Learning Opportunities for American Elementary and Secondary Students," J. Educ. Multimed. Hypermedia, vol. 26, no. 2, pp. 131-159, 2017.

[20] OECD, "Teaching And Learning International Survey," 2008.

[21] E. Villegas-reimers, "Teacher professional development : an international review of the literature," Production, pp. 1-197, 2003.

[22] R. K. Blank, N. De las Alas, and C. Smith, "Does teacher professional development have effects on teaching and learning? Analysis of evaluation findings from programs in 14 states," 2008.

[23] V. C. Smith, A. Lange, and D. R. Huston, "Predictive modeling to forecast student outcomes and drive effective interventions in online community college courses," J. Asynchronous Learn. Netw., 2012. https://doi.org/10.24059/olj.v16i3.275

[24] H. Borko, "Professional Development and Teacher Learning: Mapping the Terrain," Educ. Res., vol. 8, no. November 2004, pp. 3-15, 2004.

[25] M. S. Garet, A. C. Porter, L. M. Desimone, B. F. Birman, and S. Y. Kwang, "What Makes Professional Development Effective?Results from a National Sample of Teachers," American Educational Research 2001. https://doi.org/10.3102/00028312038004915

[26] F. Caena, "Literature review: Quality in teachers' continuing professional development," no. June, p. 20, 2011.

[27] L. M. Desimone, "Improving Impact Studies of Teachers' Professional Development: Toward Better Conceptualizations and Measures," Educ. Res., vol. 38, no. 3, pp. 181-199, 2009. https://doi.org/10.3102/0013189x08331140

[28] H. S. Kang, J. Cha, and B.-W. Ha, "What Should We Consider in Teachers' Professional Development Impact Studies? Based on the Conceptual Framework of Desimone," Creat. Educ., vol. 04, no. 04, pp. 11-18, 2013. https://doi.org/10.4236/ce.2013.44a003

[29] M. Barnett, "Technologies for Teacher Professional Development : a Critical Review of The Literature," J. Technol. Teach. Educ., 2002.

[30] A. Kennedy, "Models of Continuing Professional Development :," J. In-service Educ., vol. 31, no. 2, pp. 235-250, 2005.

[31] H. C. Wang and Y. F. Chiu, “Assessing e-learning 2.0 system success,” Comput. Educ., vol. 57, no. 2, pp. 1790-1800, 2011.

[32] J. DeMonte, "High-Quality Professional Development for Teachers," Support. Teach. Train. To Improv. Student Learn., no. July, p. 12, 2013.

[33] M. Burns, "Distance Education for Teacher Training: Modes, Models, and Methods," p. 338, 2011. 
[34] M. J. Kruger-Ross and R. D. Waters, "Predicting online learning success: Applying the situational theory of publics to the virtual classroom," Comput. Educ., vol. 61, no. 1, pp. 176-184, 2013. https://doi.org/10.1016/j.compedu.2012.09.015

[35] V. Kovanović, D. Gašević, S. Joksimović, M. Hatala, and O. Adesope, "Analytics of communities of inquiry: Effects of learning technology use on cognitive presence in asynchronous online discussions," Internet High. Educ., vol. 27, pp. 74-89, 2015. https://doi.org/10.1016/j.iheduc.2015.06.002

[36] C. Keller and L. Cernerud, "Students' Perceptions of E-learning in University Education," J. Educ. Media, vol. 27, no. 1-2, pp. 55-67, 2007.

[37] R. B. Kozma, "Global perspectives: Innovative technology integration practices from around the world," Learn. Lead. with Technol., vol. 31, no. 2, pp. 6-9,52-54, 2003.

[38] R. B. Kozma and W. S. Vota, "ICT in developing countries: Policies, implementation, and impact," in Handbook of Research on Educational Communications and Technology: Fourth Edition, 2014. https://doi.org/10.1007/978-1-4614-3185-5 72

[39] P. C. Sun, R. J. Tsai, G. Finger, Y. Y. Chen, and D. Yeh, "What drives a successful eLearning? An empirical investigation of the critical factors influencing learner satisfaction," Comput. Educ., 2008. https://doi.org/10.1016/j.compedu.2006.11.007

[40] M. Kaur, "Blended Learning - Its Challenges and Future," Procedia - Soc. Behav. Sci., vol. 93, pp. 612-617, 2013.

[41] N. H. Olitsky and S. B. Cosgrove, "The effect of blended courses on student learning: Evidence from introductory economics courses," Int. Rev. Econ. Educ., vol. 15, pp. 17-31, 2014. https://doi.org/10.1016/j.iree.2013.10.009

[42] R. Owston, H. Wideman, J. Murphy, and D. Lupshenyuk, "Blended teacher professional development: A synthesis of three program evaluations," vol. 11, no. 3-4, pp. 201-210, Jan. 2008. https://doi.org/10.1016/j.iheduc.2008.07.003

[43] C. Dede, D. J. Ketelhut, P. Whitehouse, L. Breit, and E. M. McCloskey, "A research agenda for online teacher professional development," J. Teach. Educ., vol. 60, no. 1, pp. 8-19, 2009. https://doi.org/10.1177/0022487108327554

[44] B. R. Belland, R. Burdo, and J. Gu, "A Blended Professional Development Program to Help a Teacher Learn to Provide One-to-One Scaffolding," J. Sci. Teacher Educ., vol. 26, no. 3, pp. 263-289, 2015. https://doi.org/10.1007/s10972-015-9419-2

[45] C. R. Graham, Emerging practice and research in blended learning Running Head: RESEARCH IN BLENDED LEARNING The following is a draft version from a chapter soon to be printed in the Handbook of Distance Education . Graham , C . R . ( 2013 ). Emerging practice and rese, no. June. 2014. https://doi.org/10.4324/9780203803738.ch21

[46] V. T. Ho, Y. Nakamori, T. B. Ho, and C. P. Lim, "Blended learning model on hands-on approach for in-service secondary school teachers: Combination of E-learning and face-toface discussion," Educ. Inf. Technol., vol. 21, no. 1, pp. 185-208, 2016. https://doi.org/10.1007/s10639-014-9315-y

[47] L. M. Jeffrey, J. Milne, G. Suddaby, and A. Higgins, "Blended Learning: How Teachers Balance the Blend of Online and Classroom Components," J. Inf. Technol. Educ., vol. 13, pp. 121-140, 2014. https://doi.org/10.28945/1968

[48] J. Du Toit, "Teacher Training and Usage of ICT in Education,” Unesco, 2015.

[49] J. Tondeur, J. van Braak, P. A. Ertmer, and A. Ottenbreit-Leftwich, "Understanding the relationship between teachers??? pedagogical beliefs and technology use in education: a systematic review of qualitative evidence," Educ. Technol. Res. Dev., pp. 1-21, 2016. https://doi.org/10.1007/s11423-016-9481-2 
[50] OECD, "Measuring innovation in education and training," Education, no. June, p. 14, 2009.

[51] A. Walker, M. Recker, L. Ye, M. B. Robertshaw, L. Sellers, and H. Leary, "Comparing technology-related teacher professional development designs: A multilevel study of teacher and student impacts," Educ. Technol. Res. Dev., vol. 60, no. 3, pp. 421-444, 2012. https://doi.org/10.1007/s11423-012-9243-8

[52] S.-K. K. Wang, H.-Y. Y. Hsu, T. C. Reeves, and D. C. Coster, "Professional development to enhance teachers' practices in using information and communication technologies (ICTs) as cognitive tools: Lessons learned from a design-based research study," Comput. $\begin{array}{lllll}\text { Educ., } & \text { vol. } & 79, & \text { pp. } & 101-115,\end{array}$ https://doi.org/10.1016/j.compedu.2014.07.006

[53] C. Dede, D. Sprague, and J. Editor, "A Research Agenda for Online Teacher Professional Development,” J. Technol. Teach. Educ., vol. 14, no. 4, pp. 657-661, 2006.

[54] A. Kachelhoffer and M. S. Khine, "Bridging the digital divide, aiming to become lifelong learners," IFIP Adv. Inf. Commun. Technol., vol. 302 AICT, pp. 229-237, 2009. https://doi.org/10.1007/978-3-642-03115-1 24

[55] P. R. Albion, J. Tondeur, A. Forkosh-Baruch, and J. Peeraer, “Teachers' professional development for ICT integration: Towards a reciprocal relationship between research and practice," Educ. Inf. Technol., vol. 20, no. 4, pp. 655-673, 2015. https://doi.org/10.1007/s10639-015-9401-9

[56] J. E. Jiménez and I. O'Shanahan, "Effects of web-based training on Spanish pre-service and in-service teacher knowledge and implicit beliefs on learning to read," Teach. Teach. Educ., vol. 55, pp. 175-187, 2016. https://doi.org/10.1016/j.tate.2016.01.006

[57] C. P. Kao and C. C. Tsai, "Teachers' attitudes toward web-based professional development, with relation to Internet self-efficacy and beliefs about web-based learning," Comput. Educ., vol. 53, no. 1, pp. 66-73, 2009. https://doi.org/10.1016/j.compedu.2008.12.019

[58] C. P. Kao, Y. T. Wu, and C. C. Tsai, "Elementary school teachers' motivation toward webbased professional development, and the relationship with Internet self-efficacy and belief about web-based learning," Teach. Teach. Educ., vol. 27, no. 2, pp. 406-415, 2011. https://doi.org/10.1016/j.tate.2010.09.010

[59] Y. Chen, N. S. Chen, and C. C. Tsai, "The use of online synchronous discussion for webbased professional development for teachers," Comput. Educ., vol. 53, no. 4, pp. 11551166, 2009. https://doi.org/10.1016/j.compedu.2009.05.026

[60] P. Beach, "Self-directed online learning: A theoretical model for understanding elementary teachers' online learning experiences," Teach. Teach. Educ., vol. 61, pp. 60-72, 2017. https://doi.org/10.1016/j.tate.2016.10.007

[61] N. V Smith, "Face-to-face vs. blended learning: Effects on secondary students 'perceptions and performance," Procedia - Soc. Behav. Sci., vol. 89, pp. 79-83, 2013. https://doi.org/10.1016/j.sbspro.2013.08.813

[62] B. Means, Y. Toyama, R. Murphy, M. Bakia, and K. Jones, "Evaluation of EvidenceBased Practices in Online Learning," Structure, p. 66, 2009.

[63] M. Means, B. Toyama, T., Murphy, R., Baki, "The effectiveness of online and blended learning: A meta-analysis of the empirical literature.," Teach. Coll. Rec., 2013.

[64] Y. Enoch and Z. Soker, "Age, gender, ethnicity and the digital divide: university students' use of web-based instruction," Open Learn., vol. 21, no. 2, pp. 99-110, 2006. https://doi.org/10.1080/02680510600713045 
[65] M.-L. Hung, "Teacher readiness for online learning: Scale development and teacher perceptions," Comput. Educ., vol. 94, pp. 120-133, 2016. https://doi.org/10.1016/j.compedu.2015.11.012

[66] N. Hrtoňová, J. Kohout, L. Rohlíková, and J. Zounek, "Factors influencing acceptance of e-learning by teachers in the Czech Republic," Comput. Human Behav., vol. 51, pp. 873879, Oct. 2015. https://doi.org/10.1016/j.chb.2014.11.018

[67] H. R. Chen and H. F. Tseng, "Factors that influence acceptance of web-based e-learning systems for the in-service education of junior high school teachers in Taiwan," Eval. Program Plann., vol. 35, no. 3, pp. 398-406, 2012. https://doi.org/10.1016/j.evalprogplan.2011.11.007

[68] Ö. Çakır and M. B. Horzum, “Adaptation Motivation toward Web-based Professional Development Scale and Examining Pre-service Teachers Motivation toward Web-based Professional Development Perception in Terms of Different Variables," Procedia - Soc. Behav. Sci., vol. 131, pp. 2014. https://doi.org/10.1016/j.sbspro.2014.04.094

[69] S. Papadakis, "Evaluating pre-service teachers' acceptance of mobile devices with regards to their age and gender: a case study in Greece," Int. J. Mob. Learn. Organ., vol. 12, no. 4, p. 336, 2018. https://doi.org/10.1504/ijmlo.2018.10013372

[70] M. A. Handley, C. Lyles, C. McCulloch, and A. Cattamanchi, "Selecting and Improving Quasi-Experimental Designs in Effectiveness and Implementation Research,” Ssrn, 2018. https://doi.org/10.1146/annurev-publhealth-040617-014128

[71] X. López, J. Valenzuela, M. Nussbaum, and C. C. Tsai, "Some recommendations for the reporting of quantitative studies," Computers and Education, vol. 91. pp. 106-110, 2015. https://doi.org/10.1016/j.compedu.2015.09.010

[72] Monika L. Louws, Jacobiene A. Meirink, Klaas van Veen, and Jan H. van Driel, “*** Teachers' self-directed learning and teaching experience: What, how, and why teachers want to learn," Teach. Teach. Educ., vol. 66, pp. 171-183, 2017. https://doi.org/10.1016/j.tate.2017.04.004

[73] J. Steinbach and H. Stoeger, "How primary school teachers' attitudes towards selfregulated learning (SRL) influence instructional behavior and training implementation in classrooms," Teach. Teach. Educ., vol. 60, pp. 256-269, 2016. https://doi.org/10.1016/j.tate.2016.08.017

[74] F. Li, J. Qi, G. Wang, and X. Wang, "Traditional classroom VS e-learning in higher education: Difference between students' behavioral engagement," Int. J. Emerg. Technol. Learn., vol. 9, no. 2, pp. 48-51, 2014. https://doi.org/10.3991/ijet.v9i2.3268

[75] C. S. C. Asterhan, B. B. Schwarz, and J. Gil, "Small-group, computer-mediated argumentation in middle-school classrooms: The effects of gender and different types of online teacher guidance," Br. J. Educ. Psychol., vol. 82, no. 3, pp. 375-397, 2012. https://doi.org/10.1111/j.2044-8279.2011.02030.x

[76] J. I. Rojas-Méndez, A. Parasuraman, and N. Papadopoulos, "Demographics, attitudes, and technology readiness," Mark. Intell. Plan., vol. 35, no. 1, pp. 18-39, 2017. https://doi.org/10.1108/mip-08-2015-0163

[77] D. B. Unit and S. Technology, “The Digital Divide - Barriers to e-learning,” Digit. Bridg. Unit, Sci. Technol. Innov. Dir. DFEEST, Aust. Inst. Soc. Res., no. April, 2006.

[78] V. Vitanova, T. Atanasova-Pachemska, D. Iliev, and S. Pachemska, "Factors Affecting the Development of ICT Competencies of Teachers in Primary Schools," Procedia - Soc. Behav. Sci., $\quad$ vol. $191, \quad$ pp. $1087-1094, \quad 2015$. https://doi.org/10.1016/j.sbspro.2015.04.344 
[79] R. Santos, J. Azevedo, and L. Pedro, "Digital Divide in Higher Education Students '," pp. $178-183,2013$.

[80] A. Tarhini, T. Elyas, M. A. Akour, and Z. Al-Salti, "Technology, Demographic Characteristics and E-Learning Acceptance: A Conceptual Model Based on Extended Technology Acceptance Model," High. Educ. Stud., vol. 6, no. 3, pp. 72-89, 2016. https://doi.org/10.5539/hes.v6n3p72

\section{Authors}

Wuryaningsih is Doctor in Leadership and Policy Innovation from Master and Doctoral Program in Leadership and Policy Innovation, Graduate School of Universitas Gadjah Mada, Yogyakarta, Indonesia, 55281. She currently works in The Centre for the Development and Empowerment of Educators and Educational Personnel of Art and Culture of The Ministry of Education and Culture of Indonesia, Yogyakarta, Indonesia 55581.

Dewi H. Susilastuti is a Ph.D. in Urban and Regional Planning Department of Urban and Regional Planning, Florida State University, Tallahassee, FL. She currently works as Lecturer in Masters and Doctoral in Leadership and Policy Innovation, Graduate School of Universitas Gadjah Mada, and Senior Researcher in Center for Population and Policy Studies Universitas Gadjah Mada, Yogyakarta, Indonesia 55281.

Adi Cilik Pierewan is Ph.D. in Social Change, University of Manchester. He works as Lecturer in Faculty of Social Science in Universitas Negeri Yogyakarta, Yogyakarta, Indonesia, 55281.

Muhadjir Darwin is Professor in Master and Doctoral Program in Leadership and Policy Innovation, Graduate School of Universitas Gadjah Mada, and Senior Researcher in Center for Population and Policy Studies, Universitas Gadjah Mada, Yogyakarta, Indonesia, 55281.

Article submitted 2019-04-26. Resubmitted 2019-07-19. Final acceptance 2019-07-20. Final version published as submitted by the authors. 